\title{
DUMPSTER DIVING
}

\author{
The silent treatment.
}

\section{BY ALVARO ZINOS-AMARO}

$\mathrm{D}$ aniel Weatherby, 45 , wealthy and fast dying from complications of a malignant neoplasm in the pharynx - throat cancer - was cut off from any living relatives, and unattached. But the reality of his aloneness and imminent death didn't particularly bother him. He was going to be cryogenically preserved.

"Would you like another pillow?" the nurse asked, and waited for him to gesture with his head.

Daniel had lost the use of his throat weeks ago. A man who prized silence above all else, he now wondered whether in a way the disease - if it weren't for the dying part - might not be a blessing in disguise, as he was no longer expected to talk. But lately he spent a lot of time drifting in and out of consciousness; his hands often turned blue; and his mouth was continually dry, his lips cracked. All this he could do without. He nodded and the nurse propped him up on a second foam cushion. She used glycerin swabs and lip balm to soothe his pain.

"Anything else I can do for you?"

Daniel ignored her. He had realized soon after being admitted to the hospital that one way of dismissing a caregiver was simply to stop acknowledging them.

A few moments later, when he peed himself and died, Daniel was pleased that at least he did so quietly.

He was dreaming that he was back on the sprawling Wisconsin farm of his youth. Then his eyes adjusted to the brightness of a small grey room, without windows or doors.

The first thing he felt was a complete absence of pain. He cleared his throat, which seemed to be working fine. He had been healed. Tears welled in his eyes.

He blinked. Two tall, identically dressed figures appeared by his bedside.

"What is this place?" Daniel asked.

The man and woman, eyes closed, did not reply.

Daniel tried to get out of bed, but was so weak he almost passed out.

"What year is this?"

The woman inclined her head in Daniel's direction, and then the man followed suit. Their eyes remained closed.

"Hey, you two, I'm right here! What's going on?"

The man smiled first, then the woman.

The year, by your calendar, is 2189 , an inhumanly clear voice said in Daniel's head.
"Please talk to me the old-fashioned way."

The old ways are gone, the voice said. They were problematic and had to go.

Daniel's head began to throb. This was more than dizziness.

We are very pleased about the condition of your mind, the voice said. Spacious, unadulterated.

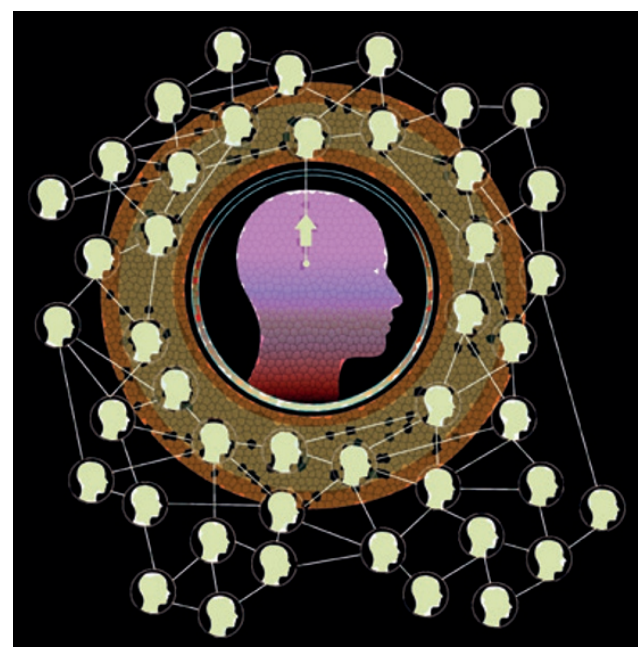

Daniel gritted his teeth. "Stop doing whatever you're doing. It's hurting me."

The examination is now over, the voice said.

His head returned to normal. Or did it? Daniel blinked. Now there were eight individuals, four men and four women. "Look, I really appreciate what you've done for me," he mumbled. "Bringing me back to life and all. But I need some fresh air, assuming it still exists in 2189. Can you show me outside?"

This time he managed to stand up, naked and all.

We've done more than that, Daniel. We've made you immortal.

A vision flashed through Daniel's mind. Idyllic parks, bountiful sunshine. Pristine mountains, lakes, oceans, forests, rivers. Extinct species restored. A thriving planetary ecosystem. Everyone smiling and in perfect health. No disease, no crime. No poverty in the world, no poverty of the mind. Everyone happy, all the time. Everyone generous and kind -

And of a kind.

"You're all ... the same?" $\rightarrow$ NATURE.COM

Follow Futures: @ @ NatureFutures $f$ go.nature.com/mtoodm
One voice, said the voice.

Daniel bolted from the bedside, intending to knock over two of his captors on his way to the farthest wall, which he planned to bang on with his bare arms and fists until someone let him out. Instead, he passed right through the figures and tumbled to the floor.

We have no wish to assimilate your consciousness into ours, said the voice. We prize that about you, that you have not heard our voice before. For we are always in need of neuronal space, and a single unconnected mind like yours would be of great value to our network.

Daniel struggled into an upright position. "What the hell do you want with my mind?"

The eight figures opened their eyes, revealing no pupils, just whites. Daniel preferred them the way they'd been before. "There were no buildings in what you showed me," he said. "We're underground, aren't we?"

A perfect world, he realized, in which all the machinery had been hidden away. And not just the machinery - but everything that was unwanted.

The refuse.

In order to maintain our calm, the voice said, we must continuously shed that part of ourselves that would lead us back to the old ways. We must shed our jealously, greed, violence and lust. Our pain and suffering.

The figures disappeared, until only one remained.

We sift through the biological scraps that survive from the past and occasionally get lucky. As with you. Perfectly preserved. Functional. Your mind will allow us to store the collected anguish of two billion people - a full tenth of the planet's population - for years. You will perform a great service for humanity, Daniel Weatherby. Because of this, and because you will perform it forever, we wished to exercise a minimum of compassion and inform you of your fate. Thank you for your contribution.

"I don't want to - "

Daniel's voice choked off. Everyone was gone.

He was alone in the room.

But not alone. Endless horrors unspooled inside his mind.

Tears fell from Daniel's eyes as he realized he would never again speak.

Alvaro Zinos-Amaro is co-author, with Robert Silverberg, of When the Blue Shift Comes (March 2014). His short fiction has previously appeared in Nature, Analog and Galaxy's Edge. 